\title{
Potensi Usaha Ternak Sapi Bali Terintegrasi Perkebunan Kelapa Sawit Di Kecamatan Wiwirano Kabupaten Konawe Utara
}

\author{
L. A. Sani, L. M. Munadi, M. R. Yosmi Antus, M. A. Pagala dan H. A. Hadini \\ Jurusan Peternakan, Fakultas Peternakan, Universitas Halu Oleo, Kendari, Sulawesi Tenggara \\ e-mail : lmmunadi@gmail.com
}

\begin{abstract}
ABSTRAK
Kecamatan Wiwirano merupakan Kecamatan di Kabupaten Konawe Utara, yang memiliki potensi untuk pengembangan usaha sapi Bali yang terintegrasi dengan perkebunan kelapa sawit. Penelitian ini bertujuan untuk mengetahui potensi usaha ternak sapi Bali terintegrasi perkebunan kelapa sawit di Kecamatan Wiwirano Kabupaten Konawe Utara. Penentuan lokasi dilakukan secara sengaja (Proposive Sampling) dengan memilih Kecamatan Wiwirano. Sampel responden diambil secara acak sederhana dari 4 desa sebanyak 60 responden. Variabel yang diukur adalah potensi usaha ternak sapi Bali berdasarkan sumber daya alam, sumber daya manusia fasilitas fisik dan non fisik menggunakan matriks internal factory analysis summery (IFAS), matriks external factory analysis summery (EFAS) matriks internal external (IE) dan matriks strength weakness oppourtunity threats (SWOT). Hasil penelitian menujukkan bahwa usaha ternak sapi bali potensial untuk dikembangkan di Kecamatan Wiwirano dengan SWOT nilai matrik IFAS yaitu $(2,96>1,0)$ stabil, nilai EFAS yaitu $(2,67>1,0)$ sehingga disimpulkan bahwa Kecamatan Wiwirano dikategorikan sebagai wilayah yang berpotensi pengembangan usaha ternak sapi Bali terintegrasi perkebunan kelapa sawit.
\end{abstract}

\section{Kata Kunci: Sapi Bali, Integrasi, Perkebunan Sawit}

\section{ABSTRACT}

Wiwirano sub-district is a sub-district in North Konawe Regency, which has the potential for the development of bali cattle business integrated with oil palm plantations. This research aims to find out the business potential of Bali cattle integrated oil palm plantations in Wiwirano District North Konawe Regency. Location determination is done deliberately (Proposive Sampling) by choosing Wiwirano Subdistrict. The sample of respondents was taken randomly from 4 villages as many as 60 respondents. The variables measured are the business potential of Bali cattle based on natural resources, human resources physical and non-physical facilities using the matrix of internal factory analysis summery (IFAS), matrix external factory analysis summery (EFAS) matrix internal external matrix (IE) and matrix strength weakness oppourtunity threats (SWOT). The results of the study showed that Bali cattle business potential to be developed in Wiwirano Subdistrict with SWOT matrix value ifas namely $(2.96>1.0)$ stable, EFAS value is $(2.67>1.0)$ so it is concluded that Wiwirano Subdistrict is categorized as an area that has the potential to develop integrated Balinese cattle business of oil palm plantations.

Keywords: Bali Cows, Integration, Palm Oil Plantation

\section{PENDAHULUAN}

Usaha ternak sapi bali merupakan salah satu usaha yang mempunyai kontribusi besar sebagai penghasil daging, untuk pemenuhan kebutuhan pangan khususnya protein hewani (Pagala et al., 2019; Hidayat et al., 2020). Kontribusi sapi Bali dalam pemenuhan komsumsi daging sapi sebesar 26,92\% (Abadi et al., 2020). Sementara itu, program pengembangan sapi 
potong dihadapkan dengan permasalahan semakin menyempitnya lahan sebagai tempat usaha dan lahan hijauan, akibat persaingan dengan sektor pertanian dalam penggunaan lahan, merupakan salah satu penyebab menurunnya populasi sapi potong (Abadi et al., 2019; Abadi, et al., 2019).

Sistem integrasi ternak sapi - kelapa sawit adalah perpaduan antara sektor peternakan dan pertanian yang sama-sama saling menguntungkan (Pagala et al., 2020). Legum dan hasil ikutan yang ada dapat dimanfaatkan sebagai pakan ternak sapi (Mudhita, 2016; Hassen et al., 2017; Prudhomme et al., 2020). Sebaliknya feses yang dihasilkan oleh ternak sapi dapat dimanfaatkan sebagai pupuk kompos untuk meningkatkan kesuburan dan produksi kelapa sawit (Bamualim et al., 2015). Disatu sisi, ternak sapi bertindak sebagai bioindustri dan juga sebagai pemberantas gulma yang ada di kebun kelapa sawit (Rostini et al., 2020).

Kecamatan Wiwirano di Kabupaten Konawe Utara memiliki potensi untuk pengembangan usaha sapi bali terintegrasi perkebunan kelapa sawit. Populasi ternak sapi sebanyak 2.329 ekor dengan luas lahan perkebunan kelapa sawit sebesar 290 Ha. Integrasi ternak sapi dan kelapa sawit juga didukung oleh potensi sumber daya alam (SDA) seperti luas lahan kelapa sawit, produktivitas lahan, ketersediaan pakan dan ketersediaan air. Sumber daya manusia (SDM) meliputi kelompok peternak, petugas penyuluh lapangan (PPL) dan tenaga kerja keluarga,serta fasilitas pendukung lainnya yaitu potensi pasar, kandang, lembaga mitra, lembaga keuangan dan pos kesehatan hewan.

\section{METODE}

Penelitian telah dilaksanakan pada bulan Oktober - November 2020, menggunakan metode survey dengan penentuan lokasi yang dilakukan secara sengaja (purposive sampling), dan memilih Kecamatan Wiwirano sebagai lokasi penelitian dengan alasan bahwa, Kecamatan Wiwirano memiliki perkebunan kelapa sawit yang terintegrasi dengan sapi bali.

Populasi dalam penelitian ini adalah seluruh peternak sapi bali dan petani kelapa sawit di Kecamatan Wiwirano Kabupaten Konawe Utara yang melakukan usaha tani kelapa sawit yang terintegrasi dengan usaha ternak sapi Bali. Sampel diambil secara acak sederhana yang terdiri dari 4 desa yang memiliki populasi ternak sapi. Masing - masing desa akan diambil 15 orang, sehingga jumlah respoden yang diambil sebanyak 60 orang respoden.

Untuk mengetahui potensi usaha ternak sapi bali terintegrasi perkebunan kelapa sawit di Kecamatan Wiwirano Kabupaten Konawe Utara menggunakan analisis SWOT (Strenght Weakness Oppourtunity Threats). Analisis ini didasarkan pada logika yang dapat memaksimalkan kekuatan (Strengths), peluang (Oppurtunities), namun secara bersamaan dapat memaksimalkan kelemahan (Weakness) dan ancaman (Threats). Analisis SWOT dibuat dalam bentuk matriks yang menggambarkan dengan jelas peluang dan ancaman eksternal yang dihadapi disesuaikan dengan kekuatan dan kelemahan yang dimilikinya disajikan pada Tabel 1. 
Tabel 1. Diagram Matriks SWOT

\begin{tabular}{|c|c|c|}
\hline & Strengths (S) & Weakness (W) \\
\hline & $\begin{array}{l}\text { Tentukan faktor-faktor } \\
\text { peluang internal. }\end{array}$ & $\begin{array}{l}\text { Tentukan faktor-faktor } \\
\text { kelemahan internal. }\end{array}$ \\
\hline Opportunities (O) & Strategi SO & Strategi WO \\
\hline $\begin{array}{l}\text { Tentukan faktor- } \\
\text { faktor } \\
\text { eksternal. }\end{array}$ & $\begin{array}{l}\text { Ciptakan strategi yang } \\
\text { menggunakan kekuatan } \\
\text { untuk memanfaatkan } \\
\text { peluang. }\end{array}$ & $\begin{array}{l}\text { Ciptakan strategi yang } \\
\text { meminimalkan } \\
\text { kelemahan } \\
\text { untuk memanfaatkan } \\
\text { peluang. }\end{array}$ \\
\hline Threats (T) & Strategi ST & Strategi WT \\
\hline $\begin{array}{l}\text { Tentukan faktor- } \\
\text { faktor } \\
\text { eksternal. }\end{array}$ & $\begin{array}{l}\text { Ciptakan strategi yang } \\
\text { menggunakan kekuatan } \\
\text { untuk mengatasi } \\
\text { ancaman. }\end{array}$ & $\begin{array}{l}\text { Ciptakan strategi yang } \\
\text { meminimalkan kelemaha } \\
\mathrm{n} \\
\text { dan } \quad \text { menghindari } \\
\text { ancaman. }\end{array}$ \\
\hline
\end{tabular}

Sumber: Rangkuti, 2004.

\section{HASIL DAN PEMBAHASAN}

Setelah mengidentifikasi faktor sumber daya alam, sumber daya manusia dan fasilitas fisik dan non fisik kemudian diidentifikasi faktor internal untuk mengetahui faktor kekuatan dan kelemahan serta faktor eksternal untuk mengetahui faktor peluang dan ancaman. Kemudian dimasukan ke matriks IFAS, matriks EFAS, matriks IE dan matriks SWOT.

\section{Matriks IFAS (Internal Factory Analisys Summery)}

Tabel 2. Matriks IFAS

\begin{tabular}{clccc}
\hline No & \multicolumn{1}{c}{ Faktor Internal } & Bobot & Rating & Nilai \\
\hline & Kekuatan (Strenght) & $\mathbf{( B )}$ & $\mathbf{( R )}$ & (BxR) \\
\hline 1 & Usia peternak produktif & 0,10 & 3 & 0,30 \\
2 & Tersedianya tenaga kerja keluarga & 0,10 & 3 & 0,36 \\
3 & Lahan kelapa sawit yang relatif luas & 0,13 & 4 & 0,52 \\
& Tersedianya sumber pakan yang & 0,10 & 4 & 0,33 \\
& memadai & & 4 & 0,31 \\
\hline & Tidak mengeluarkan biaya untuk pakan & 0,07 & & $\mathbf{1 , 8 2}$ \\
\hline$\quad$ Jumlah & & 3 & 0,33 \\
\hline 6 & Kelemahan (Weakness) & 0,11 & 3 & 0,24 \\
7 & Pingkat pendidikan masih rendah & 0,08 & 3 & 0,38 \\
8 & Pengalaman beternak rendah & 0,12 & &
\end{tabular}

Analisys factory internal summery (IFAS) yang terdiri dari faktor kekuatan (Strenght) dan kelemahan (Weakness) dalam usaha ternak sapi bali terintegrasi perkebunan kelapa sawit diperoleh 10 faktor IFAS yang terdiri dari 5 kekuatan dan 5 kelemahan yang kemudian masing-masing faktor dilakukan pembobotan, pemberian rating dan perkalian antara bobot dan rating untuk mendapatkan nilai akhir dari matriks IFAS. Lebih jelasnya disajikan pada Tabel 2. 


\begin{tabular}{|c|c|c|c|c|}
\hline 9 & \multirow{2}{*}{$\begin{array}{l}\text { Sistem pemeliharaan yang masih ekstensif } \\
\text { Tenaga penyuluh lapangan belum bekerja } \\
\text { secara optimal }\end{array}$} & 0,10 & 1 & 0,10 \\
\hline 10 & & 0,09 & 1 & 0,09 \\
\hline & Jumlah & & & 1,14 \\
\hline & Total Faktor Internal (SW) & 1 & & 2,96 \\
\hline
\end{tabular}

Data Tabel 2 menunjukkan bahwa, faktor internal terdiri dari kekuatan dan kelemahan dan masing-masing mempunyai skor yaitu kekuatan sebesar 1,82, kelemahan sebesar 1,14 dan total nilai matriks IFAS sebesar 2,96. Faktor kekuatan mempunyai nilai skor tertinggi yaitu lahan kelapa sawit yang relatif luas dengan skor 0,52 dan tersedianya sumber pakan yang memadai dengan skor 0,44. Hal ini sesuai dengan pendapat Ilham dan Saliem (2011) bahwa lahan dibawah perkebunan kelapa sawit ditumbuhi oleh banyak rerumputan, leguminosa dan semak yang dapat dimakan ternak yang berpotensi dijadikan tempat usaha integrasi sapi-sawit. Faktor kelemahan mempunyai skor terendah atau yang menjadi kelemahan utama yaitu sistem pemeliharaan yang masih ekstensif dengan skor 0,10 dan tenaga penyuluh lapangan belum bekerja secara optimal dengan skor 0,09 . Hasil analisis matriks IFAS ini menunjukan bahwa nilai kekuatan lebih besar dibandingkan dengan nilai kelemahan, maka kekuatan dapat mengatasi kelemahan yang dihadapi oleh peternak sapi Bali yang terintegrasi dengan perkebunan kelapa sawit dalam menjalankan usahanya.

\section{Matriks EFAS (External Factory Analisys Summery)}

Analisys factory exsternal summery (EFAS) dilakukan untuk mengetahui peluang (Oppourtunity) dan ancaman (Threast) yang mempengaruhi usaha sapi bali yang terintegrasi dengan perkebunan kelapa sawit di Kecamatan Wiwirano, maka diperoleh 10 faktor EFAS yang terdiri dari 5 peluang dan 5 ancaman yang kemudian dilakukan pembobotan, pemberian rating dan perkalian antara bobot dan rating untuk menggetahui nilai akhir dari matriks EFAS. Lebih jelasnya disajikan pada Tabel 3.

Tabel 3. Matriks EFAS

\begin{tabular}{clccc}
\hline No & Faktor Eksternal & Bobot & Rating & Nilai \\
\hline & Peluang (Oppourtunity) & (B) & (R) & (BxR) \\
\hline 1 & Akses transportasi yang cukup baik & 0,11 & 4 & 0,44 \\
2 & Kebijakan bantuan ternak & 0,11 & 3 & 0,33 \\
3 & Tersedianya lembaga keuangan & 0,12 & 3 & 0,36 \\
4 & Tersedianya pakan hasil dari perkebunan sawit & 0,09 & 3 & 0,27 \\
5 & Saluran pemasaran mudah & 0,08 & 3 & 0,24 \\
\hline$\quad$ Jumlah & & & $\mathbf{1 , 6 4}$ \\
\hline$\quad$ Ancaman (Threats) & 0,10 & 2 & 0,20 \\
\hline 6 & Ketersediaan air terbatas & 0,11 & 3 & 0,33 \\
7 & Pencurian ternak & 0,11 & 3 & 0,33 \\
8 & Wabah penyakit & 0,07 & 1 & 0,07 \\
9 & Fasilitas fisik dan non fisik belum memadai & 0,10 & 1 & 0,10 \\
10 & Kurangnya akses informasi dan komunikasi & & & $\mathbf{1 , 0 3}$ \\
\hline & Jumlah & $\mathbf{1}$ & & $\mathbf{2 , 6 7}$ \\
\hline & Total Faktor Eksternal (OT)
\end{tabular}

Data Tabel 3 menunjukkan bahwa, nilai peluang sebesar 1,64, nilai ancaman sebesar 1,03 dan total nilai matriks EFAS sebesar 2,67. Faktor peluang diperoleh nilai skor tertinggi atau peluang utama yaitu akses transportasi dengan skor 0,44 sedangkan, faktor ancaman nilai terendah atau yang menjadi ancaman utama yaitu 
fasilitas fisik dan non fisik belum memadai dengan nilai skor 0,07 . Hasil analisis matriks EFAS menunjukan bahwa peluang lebih kuat dibandingkan ancaman dalam mengembangkan usaha ternak sapi Bali terintegrasi dengan perkebunan kelapa sawit dengan memanfaatkan peluang yang ada untuk mengatasi ancaman (Ramadhan, 2013).

\section{Matriks IE (Internal Eksternal)}

Setelah dilakukan analisis pada matriks IFAS dan EFAS hasil tersebut kemudian dianalisis menggunakan matriks IE. Menurut Abadi et al., (2016) bahwa penyusunan matriks IE bertujuan untuk memperoleh strategi ditingkat yang lebih detail. Matriks internal dan eksternal (IE) mengindikasikan 9 sel strategi tetapi umumnya sel tersebut dapat dikelompokkan menjadi tiga strategi utama untuk mempermudah dalam pemilihan alternatif strategi. Lebih jelasnya seperti disajikan pada Gambar 1.

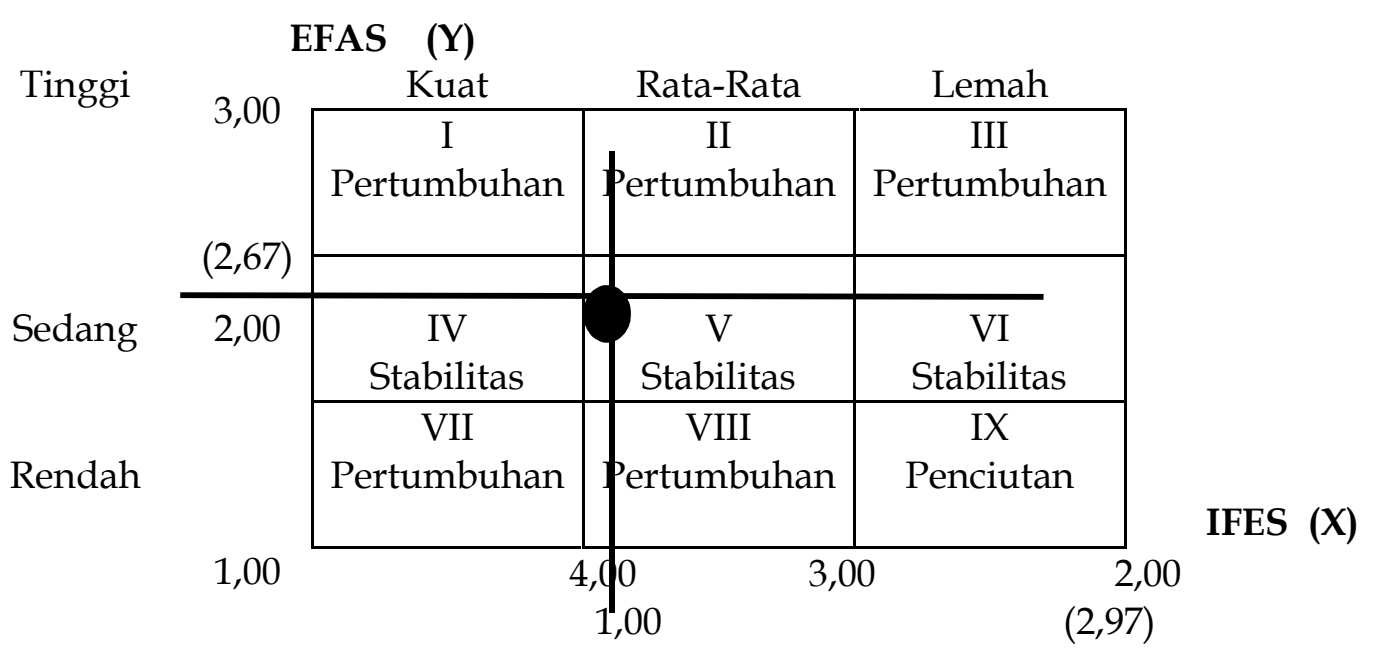

Gambar 1. Matriks Internal Eksternal Potensi Pengembangan Usaha Ternak Sapi Bali Terintegrasi Perkebunan Kelapa Sawit.

Gambar 1 matriks IE diatas menunjukkan bahwa, sumbu $X$ adalah nilai bobot IFES sebesar 2,67 dan sumbu Y adalah total nilai EFAS sebesar 2,97. Titik kordinat berada di kuadran V. Hasil tersebut menunjukkan potensi usaha ternak sapi Bali terintegrasi perkebunan kelapa sawit berada pada kondisi untuk dipertahankan dan dipelihara (hold and maintain). Hal ini sesuai dengan penelitian Kuncoro, 2010 dimana perusahaan mengalami suatu masa pertumbuhan dan dapat dikelolah dengan baik. Sesuai dengan penelitian Permatasari et al., 2015 menyatakan bahwa strategi yang tepat diterapkan pada sel $\mathrm{V}$ adalah strategi penetrasi pasar (market penetration) dan pengembangan produk (product development).

\section{Matriks SWOT (Strenght Weakness Oppourtunity Threats)}

Setelah diidentifikasi matriks IFAS, matriks EFAS dan Matriks IE selanjutnya akan dianalisis menggunakan matriks SWOT. Matriks SWOT terdiri dari faktor internal kekuatan dan kelemahan masingmasing 5, dan faktor eksternal terdiri dari peluang dan ancaman masing-masing 5 kemudian akan melahirkan 4 strategi alternatif yaitu strategi SO, WO, ST dan WT. Lebih jelas disajikan pada Gambar 2. 


\begin{tabular}{|c|c|c|}
\hline & Kekuatan (S) & Kelemahan (W) \\
\hline EFAS & $\begin{array}{l}\text { 1. Usia peternak } \\
\text { dominan produktif } \\
\text { 2. Tersedianya tenaga } \\
\text { kerja keluarga. } \\
\text { 3. Lahan kelapa sawit } \\
\text { relatif luas. } \\
\text { 4. Tersedianya sumber } \\
\text { pakan } \\
\text { yang memadai. } \\
\text { 5. Tidak mengeluarkan } \\
\text { biaya untuk pakan } \\
\text { ternak. }\end{array}$ & $\begin{array}{l}\text { 1. Tingkat pendidikan masih } \\
\text { rendah. } \\
\text { 2. Pengalaman beternak } \\
\text { masihn rendah. } \\
\text { 3. Ternak sapi bali dijadikan } \\
\text { usaha } \\
\text { Sampingan. } \\
\text { 4. Sistem pemeliharaan yan } \\
\text { g masih ekstensif. } \\
\text { 5. Tenaga penyuluh belum } \\
\text { bekerja secara optimal. }\end{array}$ \\
\hline Peluang (O) & Strategi- SO & Strategi- WO \\
\hline $\begin{array}{l}\text { 1. Akses transportasi cu } \\
\text { kup baik. } \\
\text { 2. Kebijakan bantuan } \\
\text { ternak. } \\
\text { 3. Tersedianya lembaga } \\
\text { keuangan. } \\
\text { 4. Tersedianya pakan hasi } \\
\text { 1 dari perkebunan } \\
\text { sawit. } \\
\text { 5.Saluran pemasaran } \\
\text { mudah. }\end{array}$ & $\begin{array}{l}\text { Peningkatan skala usaha } \\
\text { sapi Bali yang terintegrasi } \\
\text { perkebunan kelapa sawit. }\end{array}$ & $\begin{array}{l}\text { Peningkatan sumberdaya } \mathrm{m} \\
\text { anusia melalui sosialisasi dan } \\
\text { pelatihan. }\end{array}$ \\
\hline Ancaman (T) & Strategi -ST & Strategi- WT \\
\hline $\begin{array}{l}\text { 1. Ketersediaan air masih } \\
\text { terbatas } \\
\text { 2. Masih adanya pencuri } \\
\text { an ternak. } \\
\text { 3. Wabah penyakit. } \\
\text { 4. Fasilitas fisik dan non } \\
\text { fisik masih kurang } \\
\text { memadai. } \\
\text { 5. Kurangnya akses infor } \\
\text { masi dan komunikasi. }\end{array}$ & $\begin{array}{l}\text { Peningkatan kapasitaspet } \\
\text { ernak } \\
\text { dan petugas penyuluh } \\
\text { lapangan. }\end{array}$ & $\begin{array}{l}\text { Peran aktif lembaga peternaka } \\
\mathrm{n} \text { dan } \\
\text { pemerintah dalam mendukun } \\
\mathrm{g} \\
\text { pengembangan usaha ternak } \\
\text { sapi } \\
\text { Bali terintegrasi perkebunan } \\
\text { kelapa sawit.. }\end{array}$ \\
\hline
\end{tabular}

Gambar 2. Diagram Matriks SWOT pada Usaha Ternak Sapi Bali Integrasi Kelapa sawit di Kecamatan Wiwirano.

\section{PENUTUP}

\section{Kesimpulan}

Berdasarkan hasil penelitian disimpulkan sebagai berikut:

1. Usaha ternak sapi bali potensial untuk dikembangkan di Kecamatan Wiwirano dukungan meliputi: (1) sumber daya alam meliputi luas lahan perkebunan sawit (242,3 Ha), jumlah ternak sapi Bali sebanyak 523 ekor, ketersediaan pakan hasil perkebunan kelapa sawit. (2) sumber daya manusia meliputi usia produktif $84 \%$ dan ketersediaan tenaga kerja keluarga $63 \%$. (3) fasilitas fisik dan non fisik meliputi akses transportasi memadai, lembaga keuangan dan saluran pemasaran mudah.

2. Berdasarkan hasil analisis SWOT nilai matrik IFAS yaitu $(2,96>1,0)$ stabil, nilai 
matriks EFAS yaitu $(2,67>1,0)$ stabil dan matriks IE faktor internal berada keadaan kondisi rata-rata dan faktor eksternal berada pada kondisi sedang. Kecamatan Wiwirano dikategorikan sebagai wilayah yang berpotensi pengembangan usaha ternak sapi bali terintegrasi perkebunan kelapa sawit.

\section{Saran}

Pengembangan Sektor peternakan terintegrasi perkebunan kelapa sawit merupakan alternatif dalam

\section{DAFTAR PUSTAKA}

Abadi, M., Nafiu, L. O., \& Karim, J. (2019). Pemetaan Potensi Sumberdaya Lahan Hijauan Pakan Ternak Sapi Bali di Kecamatan Tinanggea Kabupaten Konawe Selatan. Jurnal Ilmu Dan Teknologi Peternakan Tropis, 6(1), 124-137. https://doi.org/10.33772/jitro.v6i1.8 203.

Abadi, M., Nasiu, F., Surahmanto, S., Rizal, A., \& Fatmawati, F. (2019). The Carrying Capacity of Crop as Cow and Goat Feed in Muna Barat Regency. Buletin Peternakan, 43(3), 151-157.

https://doi.org/10.21059/buletinpet ernak.v43i3.34630.

Abadi M, S. A., A, Taridala \& Nafiu, L., O. (2016). Strategi pengembangan agribisnis ayam ras petelur pada cV. Bintani poultry shop kendari, Jurnal Ilmu dan Teknologi Peternakan Tropis, 3(3), 20-31.

Bamualim, A. M., Madarisa, F., \& Pendra, Y. (2015). Kajian Inovasi Integrasi Tanaman-Ternak melalui Pemanfaatan Hasil Ikutan Tanaman Sawit untuk Meningkatkan Produksi Sapi Lokal Sumatera Barat. Journal of Animal, 17(2), 83-93.

Hassen, A., Talore, D. G., Tesfamariam, E. H., Friend, M. A., \& Mpanza, T. D. E. (2017). Potential use of foragelegume intercropping technologies to adapt to climate-change impacts on mixed crop-livestock systems in penanggulangan kekurangan pakan di Kecamatan Wiwirano, secara umum Kabupaten Konawe Utara, peran serta langkah strategis pemerintah daerah di Kabupaten Konawe Utara dalam mewujudkan swasemda daging nasional dapat terwujud dengan memanfaatkan hasil ikutan perkebunan kelapa sawit sebagai pakan ternak dan hasil ikutan ternak dapat dijadikan sebagai sumber pupuk untuk mengembalikan unsur hara tanah.

Africa: A review. Regional Environmental Change, 17(6), 17131724.

https://doi.org/10.1007/s10113-0171131-7.

Hidayat, H., Pagala, M. A., \& Zulkarnain, D. (2020). Basis Pengembangan Kawasan Sapi Potong Berdasarkan Luas Tanaman Perkebunan dan Tanaman Pangan di Kabupeten Muna. Jurnal Sosio Agribisnis, 5(1), 43-49.

https://doi.org/10.33772/jsa.v5i1.99 16.

Kuncoro. (2010). Analisis Perumusan Strategi Bisnis pada PT Samudera Nusantara Logstrindo. Binus Business Review, 1(1) : 169- 184.

Mudhita, I. K. (2016). Effect of Bali cattle urine on legume cover crop puero (Pueraria javanica) productivity on an east borneo oil palm plantation. In Pakistan Journal of Nutrition, 15(5), 406-411, https://doi.org/10.3923/pjn.2016.40 6.411.

Nafiu, L. O., Abadi, M., Aku, A. S., \& Zulkarnain, D. (2020). Pemberdayaan Peternak Melalui Bimbingan Teknis Seleksi Bibit Sapi Bali Pada Kawasan Sentra Bibit Sapi Bali Di Kabupaten Konawe Selatan. JURNAL PengaMAS, 3(2), 145-156.

Pagala, M. A., Munadi, L. O., \& Zulkarnain, D. (2019). Diversity And Green Types Carrying Capacity Bali Beef In 
Oil Palm Plantation In Kolaka District. Indonesian Journal of Animal Agricultural Science, 1(1), 48-55.

Pagala, M. A., Zulkarnain, D., \& Munadi, L. M. (2020). Kapasitas Daya Tampung Hijauan Pakan Ternak dan Hasil Ikutan Perkebunan Kelapa Sawit di Kecamatan Tanggetada Kabupaten Kolaka. Jurnal Sosio Agribisnis, 5(2), 70-76.

Permatasari, Hamid, dan Wilopo. (2015). Penentuan strategi bisnis manajemen hotel dalam menghadapi persaingan (Studi Kasus di Quds Royal Hotel Surabaya). E-journal, 27(1), 1-8.

Prudhomme, R., Brunelle, T., Dumas, P., Le Moing, A., \& Zhang, X. (2020). Assessing the impact of increased legume production in Europe on global agricultural emissions. Regional Environmental Change, 20(3), 91-98.

https://doi.org/10.1007/s10113-02001651-4.

Ramadhan, (2013). Analisis SWOT sebagai landasan dalam menentuhkan strategi pemasaran. [Tesis]. Universitas Sumatra Utara. Padang.

Rostini, T., Djaya, S., \& Adawiyah, R. (2020). Analisis Vegetasi Hijauan Pakan Ternak di Area Integrasi dan Non Integrasi Sapi dan Sawit. Jurnal Sain Peternakan Indonesia, 15(2), 155-161. https://doi.org/10.31186/jspi.id.15. 2.155-161. 